so physically or mentally defective that they would have died in childhood but for the philanthropic care received, a large number of these will remain below the standard of ability to propagate their kind, and others will be so far raised by the care received as to become sound members of the race. The intermediate class, consisting of those unfit who have been enabled by special aid to live and to become parents, will be subject to the conditions already pointed out; there will be "a regression to the normal or the stock dies out" in a very few generations. These are again general impressions and appeals to probability, but so are the statements which they controvert; we need facts. Well, but we are informed that the birth-rate of the mentally defective is high, and the Report of the Royal Commission on the Feeble-minded is freely referred to in support of this statement. I turn to this Report and find, indeed, mention of various instances of weak-minded women who had large families of children. But when the Commissioners come to sum up the matter judicially they state (vol. viii., p. 198), "With one or two exceptions, sifted and precise statements on the subject are wanting." Again. "It is, we feel, a matter of serious regret that more scientific evidence on the birth- and death-rates of the mentally defective is not forthcoming." It is plain, therefore, that the Report furnishes no sufficient ground for the assertion of a higher birth-rate. Dr. Mott's recent Huxley Lecture ${ }^{2}$ on the Hereditary Aspects of Nervous and Mental Diseases touches little on the question of fertility. He states, however: "In a number of pedigrees obtained from an imbecile asylum ..... I observe (though the numbers are not sufficient yet to give any precise data) that the families are prolific ...... but there is relatively a larger number of deaths from various diseases, especially tuberculcsis." Such pedigrees, traced upwards from offspring, will naturally deal more with the fertile than with the sterile members of the unfit class.

It would help much to the fuller understanding of this question if vital statistics of the feeble-minded and other varieties of the unfit could be compiled upon a broader basis. They must, however, take note of several generations. It would not be enough to show that feeble-minded women had as large or larger families than sound women, for the vitality and power of procreation possessed by these children must be taken into the account. It will probably be found that many die in infancy and childhood. Meantime, until proof is shown of the exceptional power of the unfit to perpetuate their kind I submit that the opposite view holds the field, and that the influence, both of natural laws and of philanthropic effort, is to raise the stock and not to lower it. I am, Sir, yours êaithfully,

Wimpole-street, $\mathrm{W}$. R. HINGsToN Fox.

\section{CONTINUOUS PROCTOCLYSIS.}

\section{To the Editor of THF LANCET.}

SIR,-The chief difficulty in the management of continuous proctoclysis lies in the maintenance of the temperature of the saline solution at a uniform degree. The possessor of a "thermos" flask is provided with a simple means of overcoming this difficulty. All the additional apparatus necessary are a $U$-shaped piece of glass tubing with one arm long enough to reach to the bottom of the flask; three or four feet of rubber tubing attached by one end to the glass tube and connected with the catheter by the other; and, lastly, some means of limiting the flow, such as a metal clip on the rubber tube or the introduction of a tap, such as that supplied with the Rotunda douche. The flask is filled with saline solution at a temperature a few degrees above that at which it is desired to administer the injection, and suspended two or three feet above the patient's bed. The fluid is then run off by syphonage and the flow regulated by the tap or clip. The temperature of the solution will remain at practically the same level, while the bottle slowly empties. At the rate usually advised-viz., one drop per second-only $7 \frac{1}{2}$ ounces are used per hour, so that a pint thermos flask will contain sufficient solution to last for two hours.

I am, Sir, yours faithfully,

Henry W. P. Young, M.D., B.C. Cantab. Norbury, S.W., Nov. 7th, 1910.

\section{BIRMINGHAM}

(FROM OUR OWN CORRESPONDENT.)

University of Birmingham: The Walter Myers Travelling Scholarship.

THE Council of the University of Birmingham at its last meeting elected Mr. Cranston Walker, M.B., Ch.B., B.Sc. Birm., to the Walter Myers Travelling Studentship, and Dr. Walker has proceeded to the University of Freiburg in Baden to carry out a research under the direction of Professor L. Aschoff. This scholarship, which is becoming one of the most important in the medical school, is of the value of $£ 150$ per annum, and was founded by Mr. George Myers of Edgbaston for the promotion of original research, and in memory of his only son, Dr. Walter Myers, a former student of Mason University College, who died from yellow fever contracted in Brazil while investigating the cause of the disease on behalf of the Liverpool School of Tropical Medicine. The Council of the University also approved the election of Mr. John Dale, M. B., Ch. B., B.Sc. (Public Health) Birm., for a further year, he having held the scholarship for the year 1909-10 and having proved himself a student of exceptional merit. Dr. Dale is returning to Hamburg to continue his research work in public health under the direction of Professor Dunbar.

\section{Research Defence Society.}

The first public meeting of this society was held on Nov. 1st in the Midland Institute. The President, Professor Leith, presided over a large audience, and Professor P. F. Frankland, F.R.S., delivered an eloquent lecture on the Life of Pasteur. A vote of thanks to the lecturer was proposed by Canon Carnegie of the Cathedral Church and seconded by Mr. Cary Gilson, M.A., the headmaster of King Edward VI.'s Grammar School. It is intended to hold three or four such public lectures each year.

\section{Hospitai Saturday Fund.}

The entire collection for the present year up to date amounts to $£ 20,194$, which is $£ 505$ more than last year. The usual grant of $£ 10,000$ for the twentieth year in succession has been made to the various hospitals of the city. Since the inception of the Fund the following amounts have been handed to the hospitals : The General Hospital (including the Jaffray Hospital), £104,064; Queen's Hospital, $£ 57,780$; General Dispensary, £31,101; Children's Hospital, $£ 23,952$; Birmingham and Midland Kye Hospital, £17,741; and Women's Hospital, $£ 12,142$. Smaller amounts have been received by other hospitals.

Nov. 16th.

\section{LIVERPOOL.}

\section{(FroM OUR OWN CORRHSPONDENT.)}

University of Liverpool : Conferring of Honorary Degrees.

THE University of Liverpool on Nov. 14th, at the hands of the Chancellor (the Earl of Derby), conferred the honorary degree of LL.D. on the Earl of Rosebery, the Earl of Cromer, Viscount Morley of Blackburn, Sir Archibald Geikie, and the Right Hon. John Burns. The scene was a brilliant and animated one, to which the undergraduates contributed a long series of topical songs. Preceding the ceremony the Lord Mayor entertained those named above and other distinguished guests at luncheon in the town-hall, where speeches were delivered. At noon Lord Rosebery unveiled a commemorative tablet to be affixed to the Students' Union, and spoke on "The True Functions of a University Union."

\section{Liverpool Seleot Vestry: Complimentary Dinner to Mr. William Alexander.}

Mr. William Alexander, who has recently resigned the office of visiting surgeon to the Liverpool workhouse hospital after 38 years' service, was entertained at dinner by the members of the select vestry, at the Adelph1 Hotel, on Nov. 2nd. Mr. T. D. Laurence, the "father" of the select vestry, proposed the health of Mr. Alexander in a llattering speech, and presented him with an illuminated address. Mr. Alexander, in responding to the toast, thanked his hosts for the address and for the kind manner in which the toast was received by those present. He also thanked the nurses of 